University of Nebraska - Lincoln

DigitalCommons@University of Nebraska - Lincoln

2000

\title{
Genetic Characterization of H3N2 Influenza Viruses Isolated from Pigs in North America, 1977-1999: Evidence for Wholly Human and Reassortant Virus Genotypes
}

\author{
Alexander I. Karasin \\ Uni6ersity of Wisconsin - Madison \\ Melissa M. Schutten \\ Uni6ersity of Wisconsin - Madison \\ Lynn A. Cooper \\ Influenza Branch, Centers for Disease Control and Pre6ention, 1600 Clifton Road, Atlanta, GA \\ Catherine B. Smith \\ Influenza Branch, Centers for Disease Control and Pre6ention, 1600 Clifton Road, Atlanta, GA \\ Kanta Subbarao \\ Influenza Branch, Centers for Disease Control and Pre6ention, 1600 Clifton Road, Atlanta, GA \\ See next page for additional authors \\ Follow this and additional works at: https://digitalcommons.unl.edu/publichealthresources \\ Part of the Public Health Commons
}

Karasin, Alexander I.; Schutten, Melissa M.; Cooper, Lynn A.; Smith, Catherine B.; Subbarao, Kanta; Anderson, Gary A.; Carman, Suzanne; and Olsen, Christopher W., "Genetic Characterization of H3N2 Influenza Viruses Isolated from Pigs in North America, 1977-1999: Evidence for Wholly Human and Reassortant Virus Genotypes" (2000). Public Health Resources. 27.

https://digitalcommons.unl.edu/publichealthresources/27

This Article is brought to you for free and open access by the Public Health Resources at DigitalCommons@University of Nebraska - Lincoln. It has been accepted for inclusion in Public Health Resources by an authorized administrator of DigitalCommons@University of Nebraska - Lincoln. 


\section{Authors}

Alexander I. Karasin, Melissa M. Schutten, Lynn A. Cooper, Catherine B. Smith, Kanta Subbarao, Gary A. Anderson, Suzanne Carman, and Christopher W. Olsen 


\title{
Genetic characterization of $\mathrm{H} 3 \mathrm{~N} 2$ influenza viruses isolated from pigs in North America, 1977-1999: evidence for wholly human and reassortant virus genotypes
}

\author{
Alexander I. Karasin a, Melissa M. Schutten a , Lynn A. Cooper ${ }^{\text {b }}$, \\ Catherine B. Smith ${ }^{\text {b }}$, Kanta Subbarao ${ }^{b}$, Gary A. Anderson ${ }^{c}$, \\ Suzanne Carman ${ }^{\mathrm{d}}$, Christopher W. Olsen ${ }^{\mathrm{a}, *}$ \\ a Department of Pathobiological Sciences, School of Veterinary Medicine, University of Wisconsin - Madison, \\ 2015 Linden Drive West, Madison, WI 53706, USA \\ ${ }^{\mathrm{b}}$ Influenza Branch, Centers for Disease Control and Prevention, 1600 Clifton Road, Atlanta, GA 30333, USA \\ ${ }^{\mathrm{c}}$ ImmTech Biologics, LLC, 8600 West 239th Street, Bucyrus, KS 66013, USA \\ d Animal Health Laboratory, University of Guelph, Box 3612, Guelph, Ont., Canada N1H 6R8
}

Received 4 February 2000; received in revised form 5 April 2000; accepted 6 April 2000

\begin{abstract}
Since 1998, H3N2 viruses have caused epizootics of respiratory disease in pigs throughout the major swine production regions of the U.S. These outbreaks are remarkable because swine influenza in North America had previously been caused almost exclusively by H1N1 viruses. We sequenced the full-length protein coding regions of all eight RNA segments from four H3N2 viruses that we isolated from pigs in the Midwestern U.S. between March 1998 and March 1999, as well as from H3N2 viruses recovered from a piglet in Canada in January 1997 and from a pig in Colorado in 1977. Phylogenetic analyses demonstrated that the 1977 Colorado and 1997 Ontario isolates are wholly human influenza viruses. However, the viruses isolated since 1998 from pigs in the Midwestern U.S. are reassortant viruses containing hemagglutinin, neuraminidase and PB1 polymerase genes from human influenza viruses, matrix, non-structural and nucleoprotein genes from classical swine viruses, and PA and PB2 polymerase genes from avian viruses. The HA proteins of the Midwestern reassortant swine viruses can be differentiated from those of the 1995 lineage of human H3 viruses by 12 amino acid mutations in HA1. In contrast, the Sw/ONT/97 virus, which did not spread from pig-to-pig, lacks 11 of these changes.
\end{abstract}

Keywords: Influenza A virus; H3N2; Pig; Reassortment; Phylogenetic analysis

* Corresponding author. Tel.: + 1-608-2658681; fax: + 1-608-2630438.

E-mail address: olsenc@svm.vetmed.wisc.edu (C.W. Olsen). 


\section{Introduction}

H1N1 influenza viruses were first isolated from pigs in the U.S. by Shope in 1930 (Shope, 1931), although influenza-like illness was recognized clinically among American pigs in the late summer and fall of 1918 (Koen, 1919; Easterday and Hinshaw, 1992) during the H1N1 'Spanish flu' human pandemic (Murphy and Webster, 1996). Recent evidence indicates that the 1918 human viruses and the 1930 swine viruses are closely related (Taubenberger et al., 1997; Reid et al., 1999), although it remains unclear whether these early $\mathrm{H} 1 \mathrm{~N} 1$ viruses appeared first in people and then spread to pigs, or vice versa (Reid and Taubenberger, 1999; Webster, 1999). In either case, interspecies transmission of influenza viruses between pigs and people has continued to occur since that time. Zoonotic transmission of H1N1 viruses from pigs has been documented repeatedly in the U.S. (Hinshaw et al., 1978; Dasco et al., 1984; Wentworth et al., 1997), Europe (de Jong et al., 1988) and New Zealand (Eason and Sage, 1980), in some cases resulting in the death of the people involved (Smith et al., 1976; Top and Russell, 1977; Patriarca et al., 1984; Rota et al., 1989; Wentworth et al., 1994; Kimura et al., 1998). Conversely, human H3N2 influenza viruses have been isolated regularly from pigs in Europe and Asia (Shortridge et al., 1977, 1979; Nakajima et al., 1982; Ottis et al., 1982; Mancini et al., 1985; Castrucci et al., 1994; Katsuda et al., 1995).

Beyond serving as sources for direct interspecies transmission of influenza viruses to people, pigs have also been suggested to be the 'mixing vessel' host in which human and avian virus co-infection can produce reassortant influenza viruses of novel genotypes (Scholtissek et al., 1985; Scholtissek and Naylor, 1988; Webster et al., 1992). Pigs are susceptible to infection with influenza viruses of avian (Castrucci et al., 1993; Kida et al., 1994; Campitelli et al., 1997; Brown et al., 1998) as well as mammalian origin because their tracheal epithelium contains virus receptor sialyloligosaccharides with both 2,3- (preferred by avian influenza viruses) and 2,6- (preferred by mammalian influenza viruses) $N$-acetylneuraminic acid-galactose linkages (Ito et al., 1998). The pandemics of hu- man influenza in 1957 and 1968 were caused by viruses that were human/avian virus reassortants (Webster et al., 1992), and more recently, human-avian influenza virus reassortants have been isolated from commercially raised pigs in Europe (Castrucci et al., 1993) and, thereafter, from children in the Netherlands (Claas et al., 1994). In addition, wholly avian H1N1 viruses entered the swine population in Europe in 1979-1980 and have subsequently become the dominant H1N1 virus among European pigs (Pensaert et al., 1981; Scholtissek et al., 1983; Webster et al., 1992).

In contrast to Europe and Asia, human H3 and avian influenza virus infections have historically been very uncommon among pigs in North America. Surveillance studies conducted in 1976/1977 (Hinshaw et al., 1978) and 1988/1989 (Chambers et al., 1991) documented widespread classical H1 swine influenza virus infection of pigs in the North-Central U.S., with H1 seropositivity rates of up to $47 \%$ in $1976 / 1977$ and $51 \%$ in $1988 / 1989$. Seropositivity to human H3 influenza viruses, on the other hand, was very limited in both 1976/ $1977(1.4 \%)$ and 1988/1989 (1.1\%), and only three H3 viruses are reported to have been isolated from pigs in North America between 1977 and 1996 (Hinshaw et al., 1978; Bikour et al., 1994, 1995). In the $1988 / 1989$ survey, swine sera were also tested for antibodies to an avian virus, A/ Duck/Alberta/16/87 (H3N8), but none of the 2337 samples contained detectable antibodies to this virus. Therefore, throughout this period, classical swine $\mathrm{H} 1$ viruses were clearly the predominant influenza viruses infecting pigs in the U.S.

In the last 3 years, the epidemiologic pattern of swine influenza in North America has changed. In 1997-1998, we noted distinct increases in seropositivity against human $\mathrm{H} 3$ and avian viruses during influenza surveillance in Wisconsin, Iowa and Illinois (Olsen et al., 2000). Specifically, $7.6 \%$ of the pigs had hemagglutination-inhibiting (HI) antibodies against an avian $\mathrm{H} 1 \mathrm{~N} 1$ virus, A/Duck/Alberta $/ 35 / 76$, and $8 \%$ of the pigs had $\mathrm{HI}$ antibodies against a human H3N2 virus, A/Wuhan/359/95 (WUH/95). During this same time period, we also began to isolate $\mathrm{H} 3 \mathrm{~N} 2$ viruses from North American pigs. We isolated an $\mathrm{H} 3 \mathrm{~N} 2$ virus from a piglet in Canada in 1997 and four H3N2 viruses 
from pigs in the Midwestern U.S. in 1998-1999 (Table 1). With the exception of the isolate from Canada, these viruses were collected during extensive outbreaks of respiratory illness in the herds-of-origin. Additionally, one of the viruses (Sw/MN/99) was also associated with abortions in pregnant sows.

The purpose of the present study was to genetically characterize these H3N2 viruses isolated from pigs in North America between 1997 and 1999, and to compare them to an H3N2 virus isolated from a pig in Colorado in 1977, A/ Swine/Colorado/1/77 (Sw/CO/77) (H3N2) (Hinshaw et al., 1978). We determined the full-length protein coding region sequences for all eight viral RNA segments from each virus and subjected the gene sequences to phylogenetic analyses to determine the likely evolutionary origin of these viruses, as well as their relationships to each other. During the final analysis of these data, Zhou et al. (1999) described four additional H3N2 viruses isolated from pigs in the U.S. between September and December 1998, three from the Midwest (Iowa, Minnesota and Texas) and one from North Carolina. To provide the most complete evaluation possible, we have also included sequence data from these viruses in our analyses. Our results indicate that the H3N2 viruses that have infected pigs in North America since 1977 are of multiple genotypes and separate sublineages within those genotypes.

\section{Materials and methods}

\subsection{Viruses}

The Sw/ONT/97, Sw/NB/98, Sw/IA533/99, $\mathrm{Sw} / \mathrm{IA} 569 / 99$ and $\mathrm{Sw} / \mathrm{MN} / 99$ viruses were isolated as described in Table 1. The Sw/ONT/97 virus was subsequently cultivated in embryonated chicken eggs after three passages in primary pig kidney cells, although it could not be isolated in eggs from the original inoculum. The $\mathrm{Sw} / \mathrm{NB} / 98$, $\mathrm{Sw} / \mathrm{IA} 533 / 99 ， \mathrm{Sw} / \mathrm{IA} 569 / 99 ， \mathrm{Sw} / \mathrm{MN} / 99$ viruses were each passaged once in Madin-Darby canine kidney (MDCK) cells after isolation in Madin-Darby bovine kidney (MDBK) cells. The
$\mathrm{Sw} / \mathrm{CO} / 77$ virus (Hinshaw et al., 1978) was kindly provided by V. Hinshaw as an allantoic fluid stock from the Influenza Virus Repository at the University of Wisconsin - Madison.

\subsection{Virus subtype and genetic characterization}

The subtype of each virus was confirmed to be $\mathrm{H} 3 \mathrm{~N} 2$ by $\mathrm{HI}$ and neuraminidase-inhibition assays (Palmer et al., 1975), using subtypemonospecific sera. The full-length protein coding regions of all eight viral RNA segments from each of the six viruses were amplified by reverse transcription-polymerase chain reaction (RTPCR) using AMV reverse transcriptase (Promega Corporation, Madison, WI) and $P f u$ polymerase (Stratagene, LaJolla, CA). Amplifications were conducted as suggested by the enzyme suppliers, except that the RT reactions were performed using $1 \mu \mathrm{g}$ of primer per reaction, and reaction conditions of $49.5^{\circ} \mathrm{C}$ for $60 \mathrm{~min}$ for the polymerase genes and $48.5^{\circ} \mathrm{C}$ for $45 \mathrm{~min}$ for the remaining genes. Amplifications of the neuraminidase (NA), nucleoprotein (NP), matrix (M), non-structural (NS) and PB1 polymerase genes were accomplished using the SZANA + / ,- SZANP +,-- SZAM +,-- SZANS + and SZAPB $1+/-$ primers, respectively, developed by Zou (1997). Amplifications of the hemagglutinin (HA) and the PB2 and PA polymerase genes were conducted using the following primers: H3HA-30F (5'-atgaatactatcattgct-3') and H3HA-1727R (5'-tcaaatgcaaatgttg-3'); PB2-43F (5'-gaactaagagatctaat-3') and PB2-2341R (5'-agtagaaacaaggtcgt- $\left.3^{\prime}\right)$; PA-55F (5'-aaggcaatgaaagaata$\left.3^{\prime}\right)$ and PA-2152R (5'-tgtgtgaggaaggagtt-3'). (F denotes a forward primer and $\mathrm{R}$ a reverse primer.)

The sequences of the amplified genes were determined from the PCR products by cycle sequencing (ABI Big Dye, PE Applied Biosystems, Foster City, CA). Sequence comparisons at the nucleotide and deduced amino acid levels were made using DNASTAR software (Version 4.0 for Win32). The phylogenetic relationships among the virus isolates and selected reference strains were estimated from their nucleotide sequences by the 


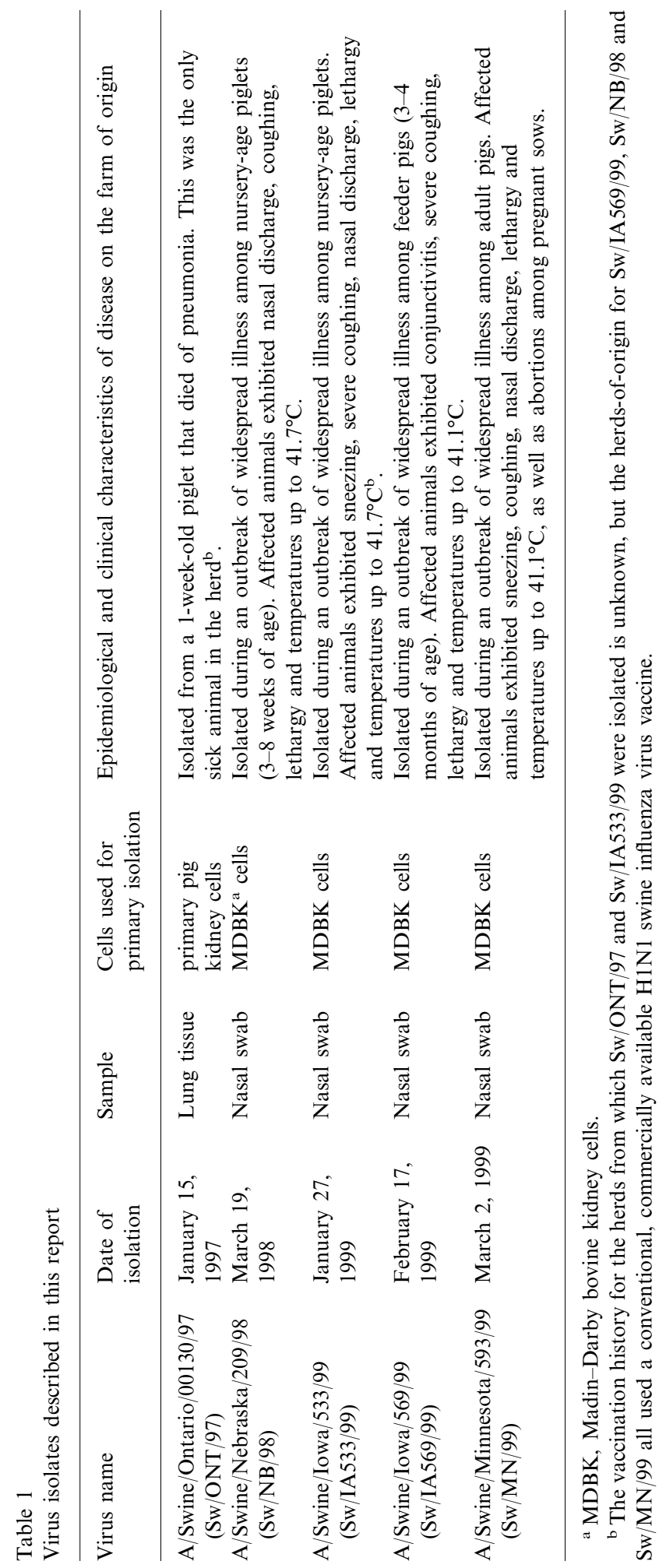


method of maximum parsimony (PAUP software v.4.0b2, David Swofford, Smithsonian Institution), using the tree-bisection-reconnection branch swapping algorithm and with the MULTREES option in effect. For the HA genes, although we determined the full-length proteincoding region sequences of our isolates, only the HA1 sequences were employed for the phylogenetic analyses because of insufficient HA2 sequence data in Gen $B \mathrm{ank}^{\mathrm{TM}}$ for reference viruses. For the other genes, the full-length coding region sequences for each of our isolates were analyzed in relation to the available reference virus sequences in Gen $B a n k^{\mathrm{TM}}$, with the 'gaps treated as missing' PAUP rule in effect.

The HA and NS sequences of $\mathrm{Sw} / \mathrm{CO} / 77$ were published previously (Bean et al., 1992; Kawaoka et al., 1998), but the sequences used in this study were re-derived from our own virus stocks. Our $\mathrm{Sw} / \mathrm{CO} / 77 \mathrm{HA}$ sequence varied at five nucleotides from that in Gen $B$ ank ${ }^{\mathrm{TM}}$, but these translated into only three conservative amino acid changes (210/ I $>$ S, 242/V $>$ I and $428 / V>L)$. Our NS gene segment sequence was identical to that in Gen $B$ ank ${ }^{\mathrm{TM}}$.

\subsection{GenBank ${ }^{\mathrm{TM}}$ accession numbers}

The Gen $B$ ank ${ }^{\mathrm{TM}}$ numbers assigned to the sequences determined during this study are as follows: AF251 389-AF251 394 (A/ Swine/Colorado/1/77); AF251 395-AF251 402 (A/Swine/Ontario/00130/97); AF251 403-AF251 410 (A/Swine/Nebraska/209/98); AF251 411AF251 418 (A/Swine/Iowa/533/99); AF251 419AF251 426 (A/Swine/Iowa/569/99); and, AF25 1427-AF251 434 (A/Swine/Minnesota/ 593/99). The Gen $B$ ank $^{\mathrm{TM}}$ accession numbers for the reference virus sequences used in the phylogenetic analyses are available upon request.

\section{Results}

\subsection{Phylogenetic analyses}

The results of the phylogenetic analyses indicate that the HA, NA and PB1 genes of $\mathrm{Sw} / \mathrm{CO} /$
77 and all of the H3N2 viruses isolated from pigs since 1997 are most closely related to the corresponding genes from human influenza viruses (Fig. 1), although of different sublineages. The HA genes of $\mathrm{Sw} / \mathrm{ONT} / 97, \mathrm{Sw} / \mathrm{NB} / 98, \mathrm{Sw} /$ IA/533/99, Sw/IA/569/99, Sw/MN/99 and the viruses isolated by Zhou et al. (1999) are most closely related to the HA genes from H3 human viruses isolated after 1995. In contrast, the $\mathrm{HA}$ gene of $\mathrm{Sw} / \mathrm{CO} / 77$, as expected from its year of isolation, was derived from the older human $\mathrm{H} 3$ lineage typified by A/Victoria/3/75. Interestingly, this older lineage also includes an $\mathrm{H} 3 \mathrm{~N} 2$ virus isolated from a pig in Canada in 1990, A/Swine/Ange-Gardien/150/90 (referred to as $\mathrm{A} / \mathrm{Swine} / \mathrm{St}-\mathrm{Hyacinthe} / 150 / 90$ by Bikour et al., 1995). In the NA and PB1 gene phylogenetic trees, the $\mathrm{Sw} / \mathrm{CO} / 77$ virus also diverges at earlier nodes than the more recent $\mathrm{H} 3 \mathrm{~N} 2$ isolates from pigs.

The results of phylogenetic analyses of the remaining internal viral protein genes clearly differentiate the genotypes of $\mathrm{Sw} / \mathrm{CO} / 77$ and $\mathrm{Sw} /$ ONT/97 from the other H3N2 swine isolates. The M, NP and NS genes (Fig. 2) of $\mathrm{Sw} / \mathrm{CO} / 77$ and $\mathrm{Sw} / \mathrm{ONT} / 97$ are of human virus origin, and in each case, these viruses are related most closely to human viruses isolated during approximately the same years. In contrast, the $\mathrm{M}$, NP and NS genes of the viruses isolated from pigs in the U.S. since 1998 are most closely related to the classical $\mathrm{H} 1 \mathrm{~N} 1$ swine viruses. In the case of the M and NS genes, the swine lineages also include $\mathrm{H} 1 \mathrm{~N} 1$ swine viruses isolated from people (A/Wisconsin/3523/88 and $\mathrm{A} / \mathrm{Wis}$ consin/4754-4755/94: $\mathrm{M}$ and NS genes) and turkeys (A/Turkey/North Carolina/1780/88: M gene). The phylogenetic analyses of the PA and PB2 genes (Fig. 3) further distinguish the genotypes of the swine $\mathrm{H} 3 \mathrm{~N} 2$ isolates. The PA and PB2 genes of $\mathrm{Sw} / \mathrm{CO} / 77$ and $\mathrm{Sw} / \mathrm{ONT} / 97$ are again most closely related to those of human viruses, the genes from the 1998 and 1999 Midwestern swine isolates are from the avian influenza virus lineage and those of $\mathrm{Sw} / \mathrm{NC} / 98$ (Zhou et al., 1999) are derived from the swine virus lineage. 


\subsection{HA gene sequence analyses}

The phylogenetic analyses characterized the overall genotypes of the swine $\mathrm{H} 3$ viruses as either wholly human, human/swine virus reassortant or human/swine/avian virus reassortant. We sought, however, to more specifically define the evolutionary origin of the HA genes of the 1997-1999 swine $\mathrm{H} 3$ viruses. To do so, we first analyzed the amino acid sequences deduced from their HA1 nucleotide sequences for the presence of the signature mutations that define the A/Johannesburg/33/94 (JOH/
94), WUH/95 and A/Sydney/05/97 (SYD/97) lineages of human $\mathrm{H} 3$ influenza viruses (Table 2). Signature amino acids are residues that identify a genetic sublineage and are conserved among all members of the group. At each of these signature residues, the HA genes from all of the swine $\mathrm{H} 3$ viruses isolated since 1997 encode the amino acids typical of the Johannesburg/33 lineage that appeared in 1994 or the Wuhan/359 lineage that appeared in 1995. None of the swine viruses contain the amino acid signature mutations of the Sydney/05 lineage that emerged in 1997.
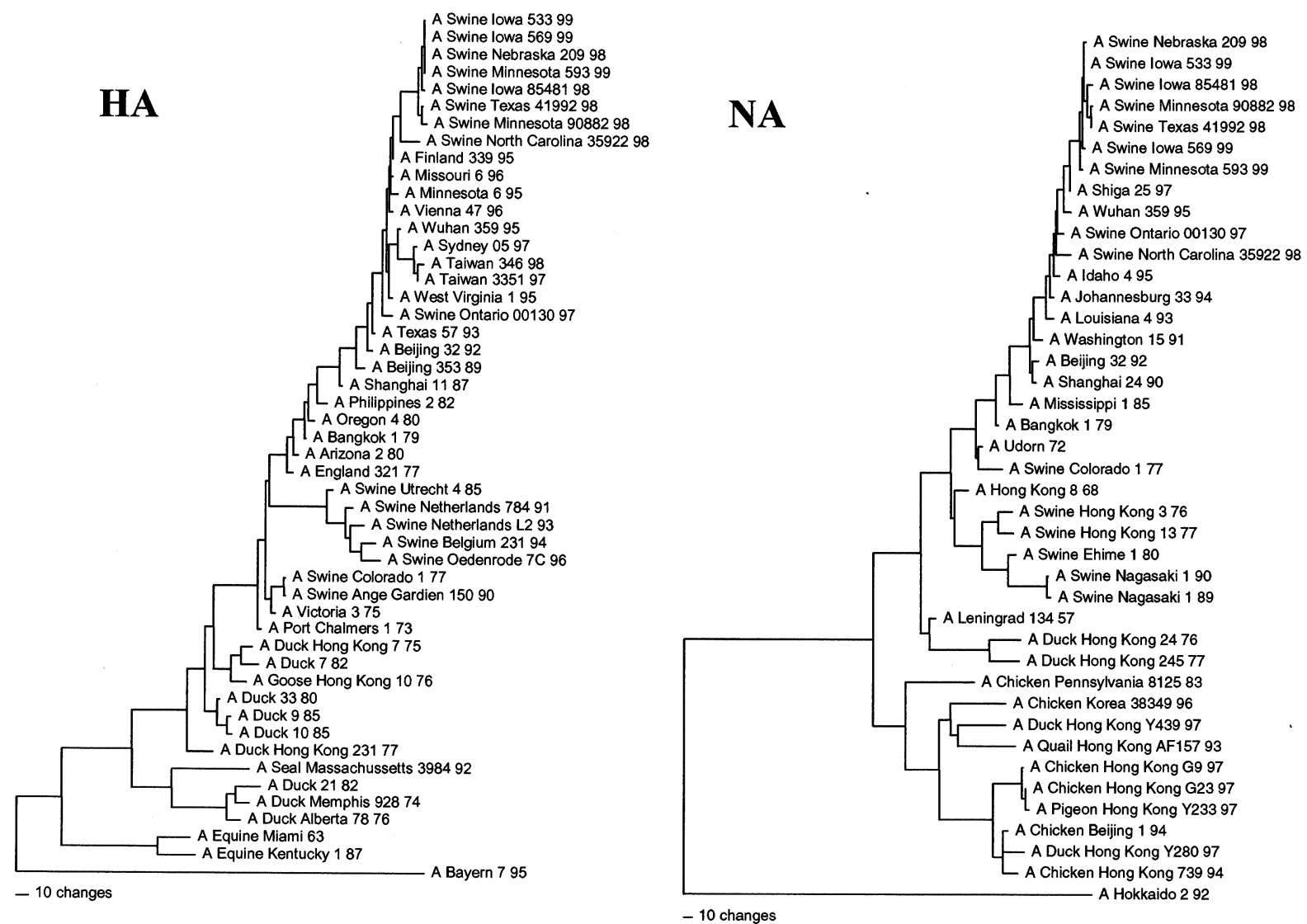

Fig. 1. Nucleotide phylogenetic trees for the HA, NA and PB1 genes of H3N2 influenza viruses isolated from pigs in North America. The evolutionary relationships were estimated by the method of maximum parsimony as described in the Section 2 . The trees shown represent the best of numerous rearrangements that were generated. The scores and number of rearrangements for each tree are as follows: HA (score 1595/258 582 rearrangements), NA (score 1998/438 796 rearrangements) and PB1 (score $2968 / 252792$ rearrangements). Horizontal line distances are proportional to the minimum number of nucleotide changes needed to join nodes and gene sequences. The vertical lines are simply for spacing the branches and labels. The HA and NA trees are rooted to influenza A viruses of different subtypes ( $\mathrm{H} 1$ and N1), whereas the PB1 tree is rooted to an influenza B virus. The Gen $B$ ank ${ }^{\mathrm{TM}}$ accession numbers for the genes of the viruses isolated during this study are listed in Section 2. The accession numbers for the reference virus sequences used in these analyses are available upon request. 


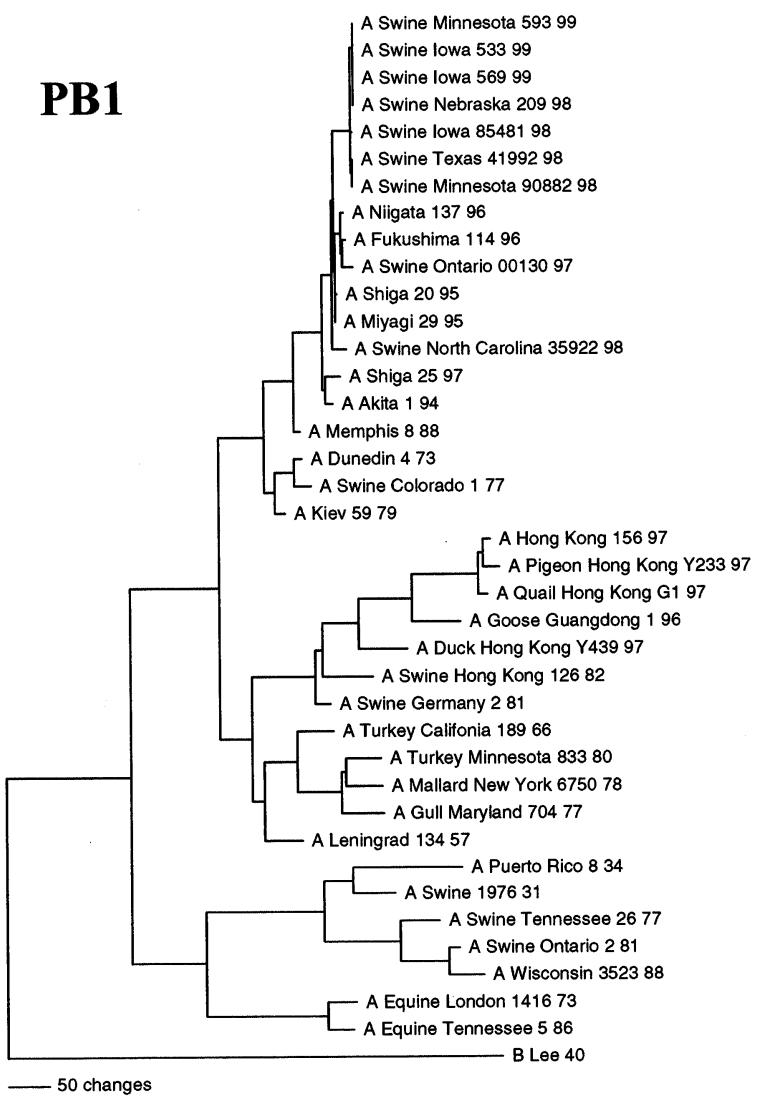

Fig. 1. (Continued)

We also investigated whether there are amino acids in the HA1 proteins that are unique to the triple reassortant human/swine/avian viruses that have spread widely throughout the pig population of the Midwestern U.S., compared to the 1995 lineage of human H3 viruses (Table 3). Twelve amino acid sites were found in which each of these reassortant swine viruses differ in sequence from the WUH/95 lineage. Mutation at one of these amino acids (246: $\mathrm{N}>\mathrm{S}$ ) would result in the loss of a potential glycosylation site in the swine viruses, and three of the other amino acids (135, 138 and 190) are among those previously defined as forming part of the receptor-binding site of the HA (Weis et al., 1988; Lamb and Krug, 1996; Zhou et al., 1999). Circulation of a 1995-lineage human H3 influenza virus among pigs in the United States between 1995 and 1998 may have provided the opportunity for these mutations to develop. Interestingly, the non-reassortant $\mathrm{Sw} /$ ONT/97 virus, which was isolated from a single sick pig in 1997, lacks 11 of these 12 amino acid changes.

\section{Discussion}

Influenza virus infection is an important cause of respiratory disease among pigs throughout the swine producing regions of the world. Classical H1N1 swine influenza virus infections typically present with clinical signs including fever, anorexia, weight loss, lethargy, nasal and ocular discharge, coughing and dyspnea (Easterday and Hinshaw, 1992). As such, the respiratory signs described for the animals/herds from which the 


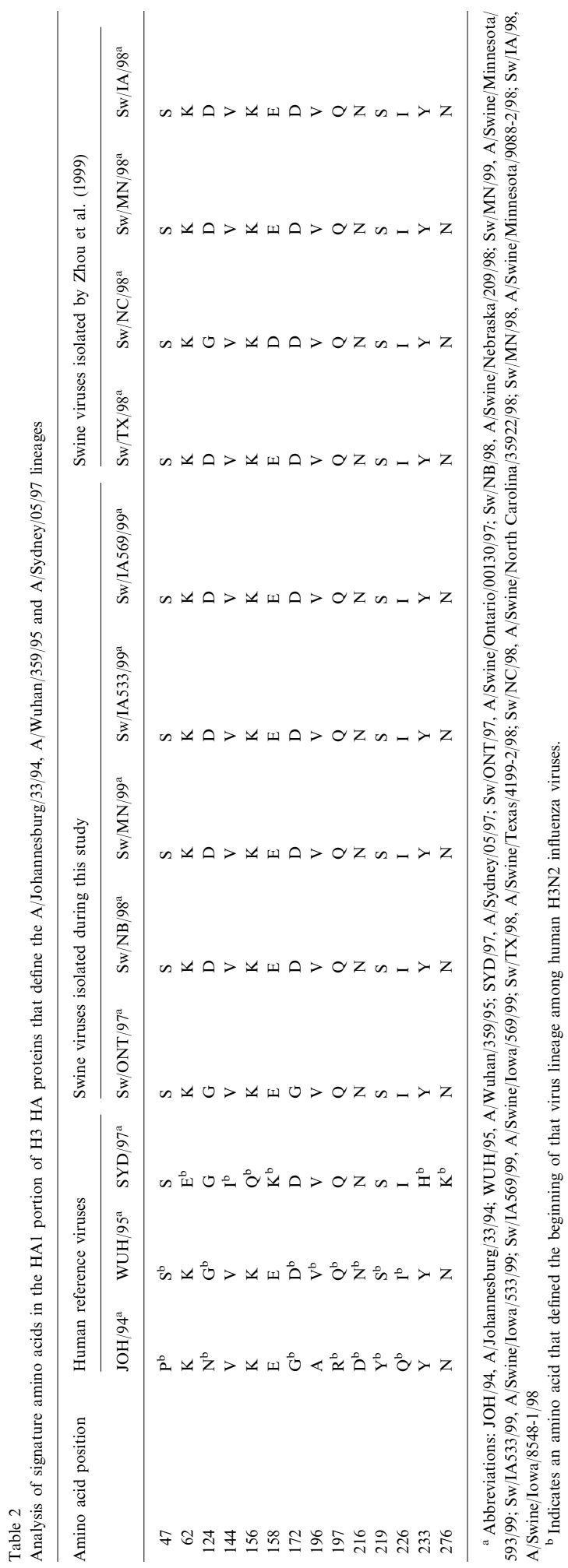


$\mathrm{Sw} / \mathrm{NB} / 98, \quad \mathrm{Sw} / \mathrm{IA} / 533 / 99, \quad \mathrm{Sw} / \mathrm{IA} / 569 / 99, \quad \mathrm{Sw} /$ $\mathrm{MN} / 99$ and $\mathrm{Sw} / \mathrm{ONT} / 97 \mathrm{H} 3 \mathrm{~N} 2$ viruses were isolated (Table 1) were not unique. However, abortions also occurred on the farm-of-origin of $\mathrm{Sw} / \mathrm{MN} / 99$ and in association with $\mathrm{H} 3 \mathrm{~N} 2$ virus infections of pigs in North Carolina (Zhou et al., 1999). Reproductive disorders have been reported only very infrequently in association with classical H1N1 swine influenza virus infections (Young and Underdahl, 1949; Madec et al., 1989) and, to our knowledge, there is only a single report in the literature identifying an $\mathrm{H} 1 \mathrm{~N} 1$ influenza virus in an aborted fetus following a naturally acquired infection of the sow (Madec et al., 1989). It will, therefore, be important to determine experimen- tally whether the reassortant $\mathrm{H} 3 \mathrm{~N} 2$ viruses infect the placenta and/or fetuses of pregnant sows to any greater degree than classical H1N1 swine influenza viruses. Alternatively, the abortions associated with $\mathrm{H} 3 \mathrm{~N} 2$ influenza virus infections may simply be due to high fevers or other metabolic disturbances in the sows.

The results of our genetic analyses demonstrate that during the past 22 years, pigs in North America have been infected with $\mathrm{H} 3 \mathrm{~N} 2$ viruses of two different genotypes. The $\mathrm{Sw} / \mathrm{CO} / 77$ and $\mathrm{Sw} /$ ONT/97 viruses are wholly human viruses, all of whose genes are most closely related phylogenetically to those of influenza viruses circulating in the human population during approximately the
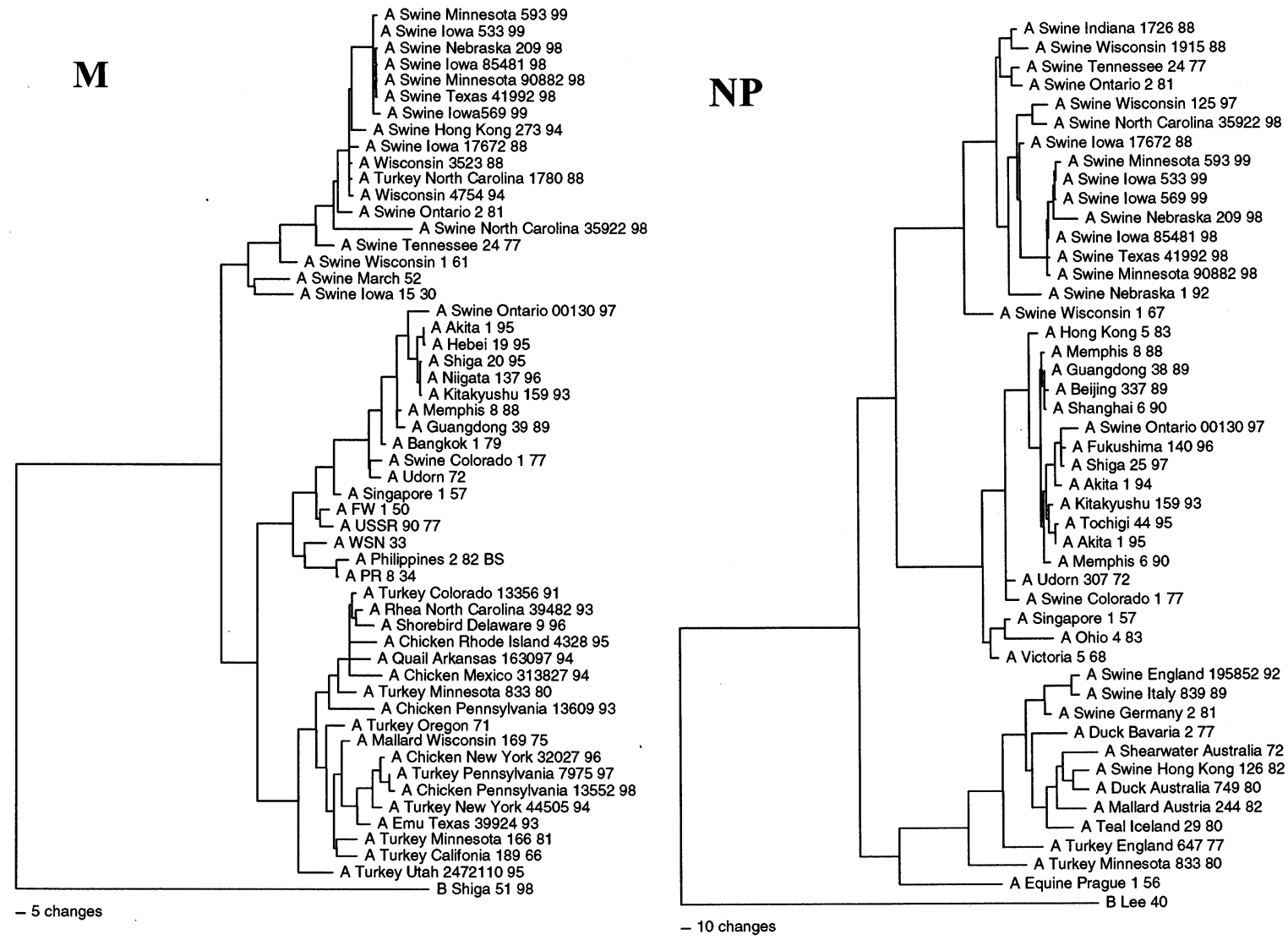

Fig. 2. Nucleotide phylogenetic trees for the M, NP and NS genes of H3N2 influenza viruses isolated from pigs in North America. The evolutionary relationships were estimated and the phylogenetic trees were constructed as described in Section 2 and in the legend for Fig. 1. The scores and number of rearrangements for each tree are as follows: M (score $975 / 11077024$ rearrangements), NP (score 2092/482 611 rearrangements) and NS (score 1271/402 217 rearrangements). All three of the trees are rooted to influenza $\mathrm{B}$ viruses. 


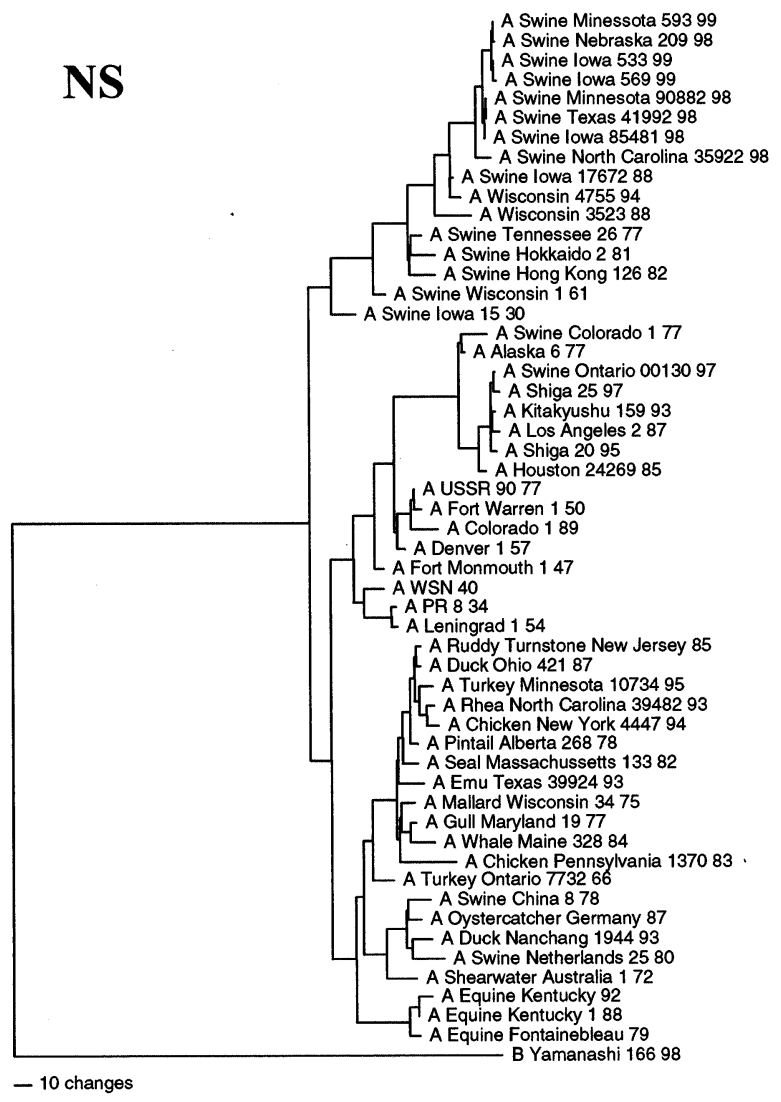

Fig. 2. (Continued)

years of their isolations (Figs. 1-3). In contrast, the viruses isolated from pigs in the U.S. since 1998 are reassortant viruses containing HA, NA and PB1 genes of human influenza virus origin, NP, $M$ and NS genes of classical swine virus origin, and PA and PB2 polymerase genes from avian or swine viruses (Figs. 1-3). As such, it is immediately clear that Sw/ONT/97 was not the direct source for the subsequent $\mathrm{H} 3 \mathrm{~N} 2$ virus infections in the U.S., despite the fact that it appeared only 14 months earlier in nearby Ontario, Canada.

The H3N2 viruses isolated from pigs in the Midwestern U.S. by Zhou et al. (1999) are of the same human/swine/avian reassortant genotype as that of our four Midwestern viruses. When the gene sequences of all seven of these viruses were examined together, we found that the Midwestern
H3N2 swine viruses share very high degrees of sequence identity with each other. At the amino acid level, the percents identity among these viruses are $98.8-100 \%$ for HA, $97.6-100 \%$ for NA, $97.0-100 \%$ for NP, 95.3-98.2\% for NS, $98.1-99 \%$ for $\mathrm{M}, 99.0-100 \%$ for PA, $99.5-100 \%$ for $\mathrm{PB} 1$ and $99.4-100 \%$ for PB2. In addition, these viruses consistently form their own phylogenetic clades for each gene segment (Figs. 1-3). Therefore, it is most plausible that these Midwestern $\mathrm{H} 3 \mathrm{~N} 2$ viruses were all derived from a single reassortant progenitor virus that subsequently spread from state-to-state, rather than as the products of multiple, independent reassortment events. Given the frequent transport of pigs throughout the country, spread of a reassortant progenitor virus could easily have occurred via the movement of infected animals. 
Since $\mathrm{Sw} / \mathrm{NC} / 98$ (Zhou et al., 1999) is a reassortant between only human and swine viruses, whereas the Midwestern swine H3N2 viruses are 3-way human/swine/avian virus reassortants, one might hypothesize that $\mathrm{Sw} / \mathrm{NC} / 98$ was an intermediary in a sequential process of reassortment. For instance, human and swine viruses might have reassorted to produce a $\mathrm{Sw} / \mathrm{NC} / 98$-like virus, followed by reassortment between that virus and an avian virus to produce the Midwestern viruses. Our recovery of a 3-way reassortant virus from a pig in Nebraska 5 months prior to the isolation of $\mathrm{Sw} / \mathrm{NC} / 98$ in North Carolina argues against this, although dates of isolation may not necessarily reflect ancestry. More definitively, however, the results of our phylogenetic analyses indicate that the human and swine virus progenitors of $\mathrm{Sw} / \mathrm{NC} /$ 98 were distinct from the progenitors of the Midwestern swine H3N2 viruses. The NA, PB1, NP and $\mathrm{M}$ phylogenies (Figs. 1 and 2) each demonstrate that $\mathrm{Sw} / \mathrm{NC} / 98$ diverged from progenitor human (NA, PB1) and swine (NP and $\mathrm{M}$ ) viruses at different points than the Midwestern clade of viruses. In addition, the sequence identity of $\mathrm{Sw} /$ $\mathrm{NC} / 98$ to the Midwestern viruses is lower for each of these gene segments (NA/96.3-97.2, NP/97.2$98.8 \%, \mathrm{M} / 90.7-91.4 \%$ and PB1/98.7-99.0\%) than the identity of the Midwestern isolates to each other (see above). Thus, $\mathrm{Sw} / \mathrm{NC} / 98$ appears to be the result of a completely unique reassortment event that was independent of the reassortment that gave rise to the Midwestern viruses.

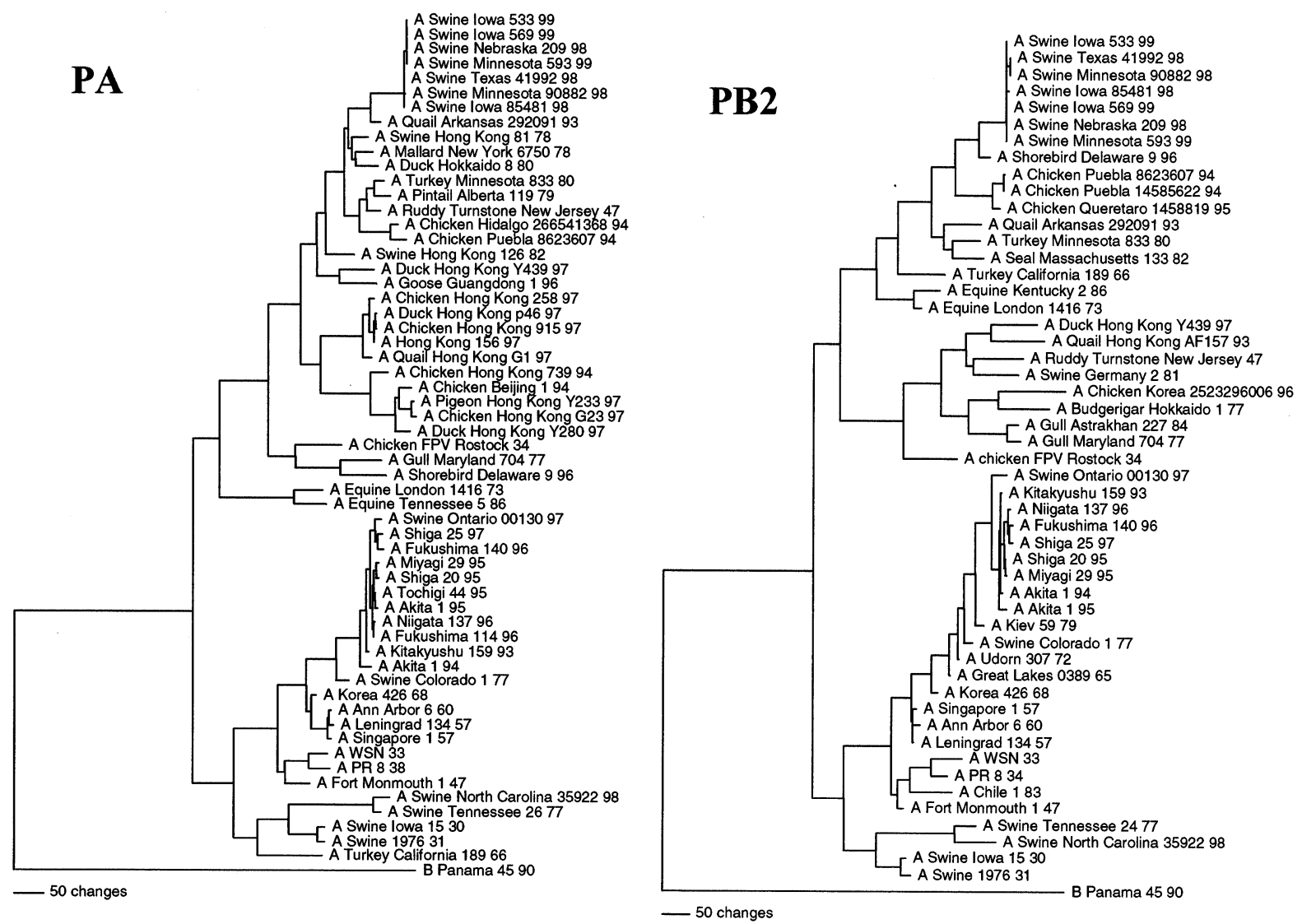

Fig. 3. Nucleotide phylogenetic trees for the PA and PB2 genes of H3N2 influenza viruses isolated from pigs in North America. The evolutionary relationships were estimated and the phylogenetic trees were constructed as described in the Section 2 and in the legend for Fig. 1. The scores and number of rearrangements for each tree are as follows: PA (score 3823/740 428 rearrangements) and PB2 (score 4207/110 568 rearrangements). Both trees are rooted to influenza B viruses. 
Table 3

Amino acids in the HA1 proteins that are uniquely different among the triple reassortant $\mathrm{H} 3 \mathrm{~N} 2$ viruses isolated from pigs in the Midwestern U.S. between March 1998 and March 1999, compared to the 1995 lineage of H3 human viruses

\begin{tabular}{|c|c|c|}
\hline $\begin{array}{l}\text { Amino acid } \\
\text { position }\end{array}$ & Swine viruses ${ }^{\mathrm{a}}$ & Human viruses ${ }^{\mathrm{b}}$ \\
\hline 88 & $\mathrm{I}^{\mathrm{c}}$ & $\mathrm{V}$ \\
\hline 106 & $\mathrm{~S}^{\mathrm{c}}$ & A \\
\hline 124 & $\mathrm{D}^{\mathrm{c}}$ & G \\
\hline 135 & $\mathrm{G}$ & $\mathrm{K} / \mathrm{T}$ \\
\hline 138 & $\mathrm{~S}^{\mathrm{c}}$ & A \\
\hline 190 & $\mathrm{E}^{\mathrm{c}}$ & $\mathrm{D}$ \\
\hline 199 & $\mathrm{I}^{\mathrm{c}}$ & $\mathrm{S}$ \\
\hline 208 & $\mathrm{~S}^{\mathrm{c}}$ & $\mathrm{R}$ \\
\hline 246 & $\mathrm{~S}^{\mathrm{c}}$ & $\mathrm{N}$ \\
\hline 278 & $\mathrm{Y}^{\mathrm{c}}$ & $\mathrm{N}$ \\
\hline 307 & $\mathrm{~K}^{\mathrm{c}}$ & $\mathrm{R}$ \\
\hline 312 & $\mathrm{~K}^{\mathrm{c}}$ & $\mathrm{N}$ \\
\hline
\end{tabular}

${ }^{a}$ Analysis includes A/Swine/Iowa/533/99, A/Swine/Iowa/ 569/99, A/Swine/Minnesota/593/99 and A/Swine/Nebraska/ $209 / 98$ isolated as part of this study, as well as A/Swine/Texas/4199-2/98, A/Swine/Minnesota/9088-2/98 and A/Swine/Iowa/8548-1/98 characterized by Zhou et al. (1999).

${ }^{\mathrm{b}}$ Analysis includes A/Wuhan/359/95 and A/Finland/339/95.

${ }^{\mathrm{c}}$ At each of these residues, A/Swine/Ontario/00130/97 contains the amino acids characteristic of the human viruses.

There is very little genetic variation among the $\mathrm{HA}$ genes of the $\mathrm{Sw} / \mathrm{NB} / 98, \mathrm{Sw} / \mathrm{IA} / 533 / 99, \mathrm{Sw} /$ IA/569/99 and $\mathrm{Sw} / \mathrm{MN} / 99$ viruses that were isolated within a 12-month period of time. The HA1 amino acid sequences of all four of these viruses were identical, and their HA2 sequences differed at only two sites $(382 / \mathrm{N}>\mathrm{D}$ in $\mathrm{Sw} / \mathrm{MN} / 99$ and $383 / \mathrm{R}>\mathrm{W}$ in $\mathrm{Sw} / \mathrm{IA} 569 / 98)$. Additionally, these viruses share a high degree of HA1 sequence identity with the Midwestern H3N2 swine viruses isolated between September and December 1998 by Zhou et al. (1999). The only differences among the later viruses were in A/Swine/Minnesota/9088$2 / 98(56 / \mathrm{H}>\mathrm{Q}, 142 / \mathrm{E}>\mathrm{G}, 209 / \mathrm{S}>\mathrm{N})$ and $\mathrm{A} /$ Swine/Texas/4199-2/98 (142/E $>$ G). These differences are not at sites previously found to be highly variable in $\mathrm{H} 3 \mathrm{HA}$ molecules or related to antigenic drift or host range determination (Bean et al., 1992), nor do they correspond to potential glycosylation sites. It will, however, be of interest to examine rates of antigenic drift and genetic evolution of $\mathrm{H} 3 \mathrm{~N} 2$ swine viruses that are isolated over the next several years. By comparison, after avian $\mathrm{H} 1 \mathrm{~N} 1$ viruses crossed the species barrier to infect pigs in Northern Europe in 1979-1980, they underwent a period of accelerated evolution that persisted through the early 1990s (Ludwig et al., 1995; Scholtissek, 1996). This rapid evolution has been attributed to either the presence of a mutator mutation in their polymerase proteins (Ludwig et al., 1995; Scholtissek, 1996) or positive selection of variants during adaptation to their new host (Stech et al., 1999). The emergence of the reassortant $\mathrm{H} 3 \mathrm{~N} 2$ viruses in the U.S. provides a second opportunity to examine virus evolution following the introduction of a novel virus into an immunologically naive swine population.

The H3N2 viruses isolated in this study may also offer a unique opportunity to directly address molecular determinants of influenza virus infectivity and replication efficiency in pigs. The triple reassortant $\mathrm{H} 3 \mathrm{~N} 2$ viruses have spread widely among pigs throughout the Midwestern U.S., whereas the wholly human $\mathrm{Sw} / \mathrm{ONT} / 97$ virus, although able to cross the species barrier to pigs, did not spread efficiently from pig-to-pig. The $\mathrm{Sw} / \mathrm{ONT} / 97$ virus was isolated from a single sick pig on one farm. The members of that farm family do not remember whether or not they were sick at the time, but there was no influenza outbreak among the other pigs on the farm. In addition, through November 1999, no additional $\mathrm{H} 3 \mathrm{~N} 2$ viruses have been isolated from pigs in the province of Ontario at the University of Guelph Animal Health Laboratory. This information strongly supports and extends the hypothesis (Zhou et al., 1999) that the specific constellation of genes present in the reassortant viruses provides a selective advantage for infectivity of pigs. Host-range restriction among influenza viruses is considered to be a polygenic trait and evidence exists for contributions by several genes (Webster et al., 1992; Murphy and Webster, 1996). However, the HA is thought to be a major contributor to host range since it is the viral protein responsible for receptor binding. In this regard, it is of particular interest that the $\mathrm{Sw} / \mathrm{ONT} / 97$ virus lacks 11 of the 12 amino acid mutations in the HA that differentiate the triple reassortant swine viruses from the 1995 lineage human H3N2 viruses. With 
the recent development of powerful new reverse genetics techniques for influenza viruses (Fodor et al., 1999; Neumann et al., 1999), it should be possible to engineer viruses that will enable us to examine the impact of these HA mutations, as well as specific constellations of the other virus genes, on influenza virus infectivity and replication efficiency in pigs.

The widespread appearance of H3N2 influenza viruses among pigs in the U.S. constitutes a significant change in the epidemiology of swine influenza in this country and an antigenic shift from the pre-existing classical H1N1 swine influenza viruses. It is not known whether both $\mathrm{H} 1 \mathrm{~N} 1$ and H3N2 viruses will continue to co-circulate among American pigs indefinitely, or whether one will eventually come to dominate. It is also not known whether these reassortant $\mathrm{H} 3 \mathrm{~N} 2$ viruses pose any enhanced threat to human health. Pigs have been shown to serve as reservoirs for older human $\mathrm{H} 3$ influenza viruses (Nakajima et al., 1982; Ottis et al., 1982; Mancini et al., 1985; Katsuda et al., 1995). As such, pigs in the U.S. may maintain these reassortant viruses and serve as a source for infection of people in the future. This would be of particular concern for children born after the disappearance of this lineage of $\mathrm{H} 3$ viruses from the human population. Finally, it also remains to be determined whether the specific constellation of swine and avian internal protein genes in these viruses will alter their virulence for humans. We have, therefore, begun active surveillance for this reassortant genotype among $\mathrm{H} 3 \mathrm{~N} 2$ viruses isolated from human beings in the Midwest during the 1999-2000 influenza virus season.

\section{Acknowledgements}

This work was supported in part by USDA Agricultural Experiment Station grant, a USDA NRICGP grant (CWO) and a Merial Summer Student Research Fellowship (MMS). The authors thank Yoshihiro Kawaoka and Diane Larsen from the University of Wisconsin Madison and Nancy Cox from the Influenza Branch of the Centers for Disease Control for many helpful discussions.

\section{References}

Bean, W.J., Schell, M., Katz, J., Kawaoka, Y., Naeve, C., Gorman, O., Webster, R.G., 1992. Evolution of the H3 influenza virus hemagglutinin from human and nonhuman hosts. J. Virol. 66, 1129-1138.

Bikour, M.H., Cornaglia, E., Weber, J.M., Elazhary, Y., 1994. Antigenic characterization of an $\mathrm{H} 3 \mathrm{~N} 2$ swine influenza virus isolated from pigs with proliferative and necrotizing pneumonia in Quebec. Can. J. Vet. Res. 58, 287-290.

Bikour, M.H., Frost, E.H., Deslandes, S., Talbot, B., Weber, J.M., Elazhary, Y., 1995. Recent H3N2 swine influenza virus with haemagglutinin and nucleoprotein genes similar to 1975 human strains. J. Gen. Virol. 76, 697-703.

Brown, I.H., Harris, P.A., McCauley, J.W., Alexander, D.J., 1998. Multiple genetic reassortment of avian and human influenza A viruses in European pigs, resulting in emergence of an H1N2 virus of novel genotype. J. Gen. Virol. 79, 2947-2955.

Campitelli, L., Donatelli, I., Foni, E., Castrucci, M.R., Fabiani, C., Kawaoka, Y., Krauss, S., Webster, R.G., 1997. Continued evolution of H1N1 and H3N2 influenza viruses in pigs in Italy. Virology 232, 310-318.

Castrucci, M.R., Donatelli, I., Sidoli, L., Barigazzi, G., Kawaoka, Y., Webster, R.G., 1993. Genetic reassortment between avian and human influenza viruses in Italian pigs. Virology 193, 503-506.

Castrucci, M.R., Campitelli, L., Ruggieri, A., Barigazzi, G., Sidoli, L., Daniels, R., Oxford, J.S., Donatelli, I., 1994. Antigenic and sequence analysis of $\mathrm{H} 3$ influenza virus haemagglutinins from pigs in Italy. J. Gen. Virol. 75, $371-379$.

Chambers, T.M., Hinshaw, V.S., Kawaoka, Y., Easterday, B.C., Webster, R.G., 1991. Influenza viral infection of swine in the United States 1988-1989. Arch. Virol. 116, 261-265.

Claas, E.C.J., Kawaoka, Y., de Jong, J.C., Masurel, N., Webster, R.G., 1994. Infection of children with avian-human reassortant influenza virus from pigs in Europe. Virology 204, 453-457.

Dasco, C.C., Couch, R.B., Six, H.R., Young, J.F., Quarles, J.M., Kasel, J.A., 1984. Sporadic occurrence of zoonotic swine influenza virus infections. J. Clin. Microbiol. 20, 833-835.

de Jong, J.C., Paccaud, M.F., de Ronde-Verloop, F.M., Huffels, N.H., Verwei, C., Weijers, T.F., Bangma, P.J., van Kregten, E., Kerckhaert, J.A.M., Wicki, F., Wunderli, W., 1988. Isolation of swine-like influenza A (H1N1) viruses from men in Switzerland and the Netherlands. Annu. Inst. Pasteur/Virol. 139, 429-437.

Eason, R.J., Sage, M.D., 1980. Deaths from influenza A, subtype H1N1, during the 1979 Auckland epidemic. New Zealand Med. J. 91, 129-131.

Easterday, B.C., Hinshaw, V.S., 1992. Swine influenza. In: Leman, A.D., Straw, B.E., Mengeling, W.L., D'Allaire, S.D., Taylor, D.J. Jr (Eds.), Diseases of Swine. Iowa State Press, Ames, IA, pp. 349-357. 
Fodor, E., Devenish, L., Engelhardt, O.G., Palese, P., Brownlee, G.G., García-Sastre, A., 1999. Rescue of influenza A virus from recombinant DNA. J. Virol. 73, 9679-9682.

Hinshaw, V.S., Bean, W.J. Jr, Webster, R.G., Easterday, B.C., 1978. The prevalence of influenza viruses in swine and the antigenic and genetic relatedness of influenza viruses from man and swine. Virology 84, 51-62.

Ito, T., Couceiro, J.N.S.S., Kelm, S., Baum, L.G., Krauss, S., Castrucci, M.R., Donatelli, I., Kida, H., Paulson, J.C., Webster, R.G., Kawaoka, Y., 1998. Molecular basis for the generation in pigs of influenza A viruses with pandemic potential. J. Virol. 72, 7367-7373.

Katsuda, K., Shirahata, T., Kida, H., Goto, H., 1995. Antigenic and genetic analyses of the hemagglutinin of influenza viruses isolated from pigs in 1993. J. Vet. Med. Sci. 57, 1023-1027.

Kawaoka, Y., Gorman, O.T., Ito, T., Wells, K., Donis, R.O., Castrucci, M.R., Donatelli, I., Webster, R.G., 1998. Influence of host species on the evolution of the nonstructural (NS) gene of influenza A viruses. Virus Res. 55, 143-156.

Kida, H., Ito, T., Yasuda, J., Shimizu, Y., Itakura, C., Shortridge, K.F., Kawaoka, Y., Webster, R.G., 1994. Potential for transmission of avian influenza viruses to pigs. J. Gen. Virol. 75, 2183-2188.

Kimura, K., Adlakha, A., Simon, P.M., 1998. Fatal case of swine influenza virus in an immunocompetent host. Mayo Clin. Proc. 73, 243-245.

Koen, J.S., 1919. A practical method for field diagnosis of swine diseases. Am. J. Vet. Med. 14, 468-470.

Lamb, R.A., Krug, R.M., 1996. Orthomxyoviridae: the viruses and their replication. In: Fields, B.N., Knipe, D.M., Howley, P.M., Chanock, R.M., Melnick, J.L., Monath, T.P., Roizman, B., Straus, S.E. (Eds.), Fields Virology. Lippincott-Raven, Philadelphia, PA, pp. 1353-1395.

Ludwig, S., Stitz, L., Planz, O., Van, H., Fitch, W.M., Scholtissek, C., 1995. European swine virus as a possible source for the next influenza pandemic. Virology 212, $555-561$.

Madec, F., Kaiser, C., Gourreau, J.M., Martinat-Botte, F., 1989. Pathologic consequences of a severe influenza outbreak (swine virus $\mathrm{A} / \mathrm{H} 1 \mathrm{~N} 1$ ) under natural conditions in the non-immune sow at the beginning of gestation. Comp. Immunol. Microbiol. Infect. Dis. 12, 17-27.

Mancini, G., Donatelli, I., Rozera, C., Ruiz, G.A., Butto, S., 1985. Antigenic and biochemical analysis of influenza A H3N2 viruses isolated from pigs. Arch. Virol. 83, 157-167.

Murphy, B.R., Webster, R.G., 1996. Orthomyxoviruses. In: Fields, B.N., Knipe, D.M., Howley, P.M., Chanock, R.M., Melnick, J.L., Monath, T.P., Roizman, B., Straus, S.E. (Eds.), Fields Virology. Lippincott-Raven, Philadelphia, PA, pp. 1397-1445.

Nakajima, K., Nakajima, S., Shortridge, K.F., Kendal, A.P., 1982. Further genetic evidence for maintenance of early Hong Kong-like influenza A (H3N2) strains in swine until 1976. Virology 116, 562-572.

Neumann, G., Watanabe, T., Ito, H., Watanabe, S., Goto, H., Gao, P., Hughes, M., Perez, D.R., Donis, R., Hoffmann,
E., Hobom, G., Kawaoka, Y., 1999. Generation of influenza A viruses entirely from cloned cDNAs. Proc. Natl. Acad. Sci. USA 96, 9345-9350.

Olsen, C.W., Carey, S., Hinshaw, L., Karasin, A.I., 2000. Virologic and serologic surveillance for human, swine and avian influenza virus infections among pigs in the northcentral United States, Arch. Virol., in press.

Ottis, K., Sidoli, L., Bachman, P.A., Webster, R.G., Kaplan, M.M., 1982. Human influenza A viruses in pigs: isolation of a H3N2 strain antigenically related to A/England/42/72 and evidence for continuous circulation of human viruses in the pig population. Arch. Virol. 73, 103-108.

Palmer, D.F., Dowdle, W.R., Coleman, M.T., Schild, G.C., 1975. Advanced laboratory techniques for influenza diagnosis. In: United States Department of Health, Education and Welfare Immunology Series.

Patriarca, P.A., Kendal, A.P., Zakowski, P.C., Cox, N.J., Trautman, M.S., Cherry, J.D., Auervach, D.M., McCusker, J., Belliveau, R.R., Kappus, K.D., 1984. Lack of significant person-to-person spread of swine influenza-like virus following fatal infection of an immunocompromised child. Am. J. Epidemiol. 119, 152-158.

Pensaert, M., Ottis, K., Vandeputte, J., Kaplan, M.M., Bachmann, P.A., 1981. Evidence for the natural transmission of influenza A virus from wild ducks to swine and its potential importance for man. Bull. WHO 59, 75-78.

Reid, A.H., Taubenberger, J.K., 1999. The 1918 flu and other influenza pandemics: 'over there' and back again. Lab. Invest. 79, 95-101.

Reid, A.H., Fanning, T.G., Hultin, J.V., Taubenberger, J.K., 1999. Origin and evolution of the 1918 'Spanish' influenza virus hemagglutinin gene. Proc. Natl. Acad. Sci. U.S.A. 96, $1651-1656$.

Rota, P.A., Rocha, E.P., Harmon, M.W., Hinshaw, V.S., Sheerar, M.G., Kawaoka, Y., Smith, T.L., 1989. Laboratory characterization of a swine influenza virus isolated from a fatal case of human influenza. J. Clin. Microbiol. 27, 1413-1416.

Scholtissek, C., Naylor, E., 1988. Fish farming and influenza pandemics. Nature 331, 215-215.

Scholtissek, C., Burger, H., Bachmann, P.A., Hannoun, C., 1983. Genetic relatedness of hemagglutinins of the $\mathrm{H} 1$ subtype of influenza A viruses isolated from swine and birds. Virology 129, 521-523.

Scholtissek, C., Burger, H., Kistner, O., Shortridge, K., 1985. The nucleoprotein as a possible major factor in determining host specificity of influenza H3N2 viruses. Virology 147, 287-294.

Scholtissek, C., 1996. Molecular evolution of influenza viruses. Virus Genes 11, 209-215.

Shope, R.E., 1931. Swine influenza. Filtration experiments and etiology. J. Exp. Med. 54, 373-385.

Shortridge, K.F., Webster, R.G., Butterfield, W.K., Campbell, C.H., 1977. Persistence of Hong Kong influenza virus variants in pigs. Science 196, 1454-1455.

Shortridge, K., Cherry, A., Kendal, A., 1979. Further studies of the antigenic properties of $\mathrm{H} 3 \mathrm{~N} 2$ strains of influenza A 
isolated from swine in Southeast Asia. J. Gen. Virol. 44, 251-254.

Smith, T.F., Burgert, E.O., Dowdle, W.R., Noble, G.R., Campbell, R.J., Van Scoy, R.E., 1976. Isolation of swine influenza virus from autopsy lung tissue of man. New Engl. J. Med. 294, 708-710.

Stech, J., Xiong, X., Scholtissek, C., Webster, R.G., 1999. Independence of evolutionary and mutational rates after transmission of avian influenza viruses to swine. J. Virol. $73,1878-1884$.

Taubenberger, J.K., Reid, A.H., Krafft, A.E., Bijwaard, K.E., Fanning, T.G., 1997. Initial genetic characterization of the 1918 'Spanish' influenza virus. Science 275, 17931796.

Top, F.H., Russell, P.K., 1977. Swine influenza at Fort Dix, N.J. IV. Summary and speculation. J. Infect. Dis. 136, S376-S380.

Webster, R.G., Bean, W.J., Gorman, O.T., Chambers, T.M., Kawaoka, Y., 1992. Evolution and ecology of influenza A viruses. Microbiol. Rev. 56, 152-179.

Webster, R.G., 1999. 1918 Spanish influenza: the secrets remain elusive. Proc. Natl. Acad. Sci. U.S.A. 96, 11641166.
Weis, W., Brown, J.H., Cusack, S., Paulson, J.C., Skehel, J.J., Wiley, D.C., 1988. Structure of the influenza virus haemagglutinin complexed with its receptor, sialic acid. Nature 333, 426-431.

Wentworth, D., Xian, X., Cooley, A.J., McGregor, M.W., Hinshaw, V.S., Cox, N., 1994. An influenza A (H1N1) virus closely related to swine influenza responsible for a fatal case of human influenza. J. Virol. 68, 2051-2058.

Wentworth, D.E., McGregor, M.W., Macklin, M.D., Neumann, V., Hinshaw, V.S., 1997. Transmission of swine influenza virus to humans after exposure to experimentally infected pigs. J. Infect. Dis. 175, 7-15.

Young, G.A., Underdahl, N.A., 1949. Swine influenza as a possible factor in suckling pig mortalities. I. Seasonal occurrence in adult swine as indicated by hemagglutinin inhibitors in serum. Cornell Vet. 39, 105-119.

Zhou, N.N., Senne, D.A., Landgraf, J.S., Swenson, S.L., Erickson, G., Rossow, K., Liu, L., Yoon, K.-J., Krauss, S., Webster, R.G., 1999. Genetic reassortment of avian, swine, and human influenza A viruses in American pigs. J. Virol. 73, 8851-8856.

Zou, S., 1997. A practical approach to genetic screening for influenza virus variants. J. Clin. Microbiol. 35, 2523-2627. 